\title{
Doping, sport and the community
}

I $\mathrm{t}$ is almost 20 years since the Ben Johnson scandal at the Olympics in Seoul, Korea, drew attention to the issue of doping. Have we made progress since then in addressing this important sport and public health concern? Will the Olympic ideal survive, or will it be lost in a sea of hormone, steroid and stimulant abuse?

In the scandal's aftermath, an independent organization now known as the Canadian Centre for Ethics in Sport was established to develop a national antidoping program. It has served as a model for other national antidoping organizations. Still, 55 Canadian athletes violated antidoping rules in the past 3 years: 27 used "recreational" drugs such as marijuana, and 28 took performanceenhancing drugs, most often anabolic steroids or stimulants.

Doping strategies often seem to outpace antidoping programs. There will always be those who seek to gain unfair advantage. Endurance can be dramatically enhanced by artificially elevating the red blood cell mass, as seen in the "blood-doping" strategies used by some athletes. By reinfusing previously stored red blood cells, or by stimulating erythropoiesis with the use of synthetic erythropoietin, known as EPO, performance can be surreptitiously increased. Detecting such manipulation is not easy. Erythropoietin products leave the system quickly, and autologous transfusions of blood cells are difficult to identify. Attempts to identify elevated hematocrit levels in the hours before competition led to the masking of such practices with intravenous hemodilution techniques. What has not gone unnoticed is the catastrophic loss of life attributed to erythropoietin in many sports - particularly cycling, which many have come to regard as a veritable incubator of doping techniques. ${ }^{1,2}$

The ability to identify anabolic steroid use continues to improve. Unannounced year-round testing has increased the detection of steroid use. Testosterone use still poses certain challenges. A sudden elevation of the testosterone-epitestosterone ratio typically indicates illegitimate use of this anabolic steroid. It is well known that some individuals may have naturally elevated ratios. But it has recently been recognized that $40 \%$ of those with a certain genotype found in two-thirds of people of Asian ancestry may not reach the threshold elevation of the ratio after administration of testosterone. ${ }^{3}$

Growth hormone, believed to be a potent anabolic agent, is difficult to detect using current methods. ${ }^{4,5}$ In the weeks to come, new detection techniques may be integrated into standard testing procedures.

Other challenges remain. Costs of antidoping programs are high, and programs are increasingly complex and difficult to manage. As the bureaucratic burden imposed on athletes, physicians and sport organizations grows, concerns about sustainability abound. But the resolve of athletes and sport organizations to maintain integrity and eradicate cheating is strong.

What about community-level athletes? Given the profile of drug use in high-performance sport, we are left to wonder about the use of anabolic steroids in the playgrounds, gymnasia and arenas of our neighbourhoods. Several years ago, it was noted that the use of anabolic steroids had crept into community sport. ${ }^{6,7} \mathrm{~A}$ recent survey documented that $3.7 \%$ of grade 12 students reported having used steroids. ${ }^{5}$ Although difficult to document, it has been postulated that more steroid use takes place outside organized sport, within body-building and other subcultures, where no attempt is made to address drug-taking behaviour. Therein lies the basis for obvious concerns. Anabolic steroids are not benign. Their use has been associated with a variety of endocrinologic, cardiovascular and behavioural complications.

Adolescent athletes, often eager to gain weight and muscle mass, are ripe targets for those who offer easy approaches that promise startling results in just a few weeks. To some, performance and size are paramount; they are seen to be the keys to success and stardom. And therein lies a special challenge for physicians interested and involved in sport: we must ensure that those athletes and, perhaps more importantly those who coach them, develop approaches to sporting success that emphasize excellence in every domain. Pharmacologic approaches to enhanced performance represent a witches' brew of distorted values and maligned perspectives with potentially devastating health risks.

Athletes are now competing on an Olympic stage. Some performances may be suspect and proven to be illegitimate. But the overwhelming majority of athletes will compete fairly and cleanly. Sadly, their accomplishments are sometimes overshadowed by the debased conduct of a minority. Athletes from Canada and from other countries are the product of sport systems that work tirelessly to address the doping scourge.

Antidoping programs in an Olympic setting ensure fair play and maintain public trust. A concern for drug use in community sport is equally important; the implications of such behaviour compel thoughtful, strategic interventions to ensure sporting integrity and public health.

\section{Andrew Pipe MD Dip Sport Med}

Minto Prevention and Rehabilitation Centre

University of Ottawa Heart Institute

\section{Paul C. Hébert MD MHSc}

Editor-in-Chief

CMAJ

Ottawa, Ont.

With the Editorial-Writing Team (Rajendra Kale MD, Matthew B. Stanbrook MD PhD, Barbara Sibbald BJ, Ken Flegel MDCM MSc, Noni MacDonald MD MSc and Amir Attaran LLB DPhil)

Competing interests: No competing interests declared for Andrew Pipe. See www.cmaj.ca/misc/edboard.shtml for the Editorial-Writing Team's statements.

\section{REFERENCES}

1. Fotheringham W. Inquiry into Belgian cyclists' deaths raises new fears over EPO. The Guardian 2004 Feb 16.

2. Lippi G, Franchini M, Guidi GC. Switch off the light on cycling, switch off the light on doping. Br J Sports Med 2008;42:162.

3. Schulze JJ, Lundmark J, Garle M, et al. Doping test results dependent on genotype of UGT2B17, the major enzyme for testosterone glucurodination. J Clin Endocrinol Metab 2008;93:2500-6.

4. Dean H. Does exogenous growth hormone improve athletic performance? Clin J Sport Med 2002;12:250-3.

5. Liu H, Bravata D, Olkin I, et al. Systematic review: the effects of growth hormone on athletic performance. Ann Intern Med 2008;148:747-58

6. Melia P, Pipe A, Greenberg L. The use of anabolic-androgenic steroids by Canadian students. Clin J Sport Med 1996;6:9-14.

7. Adlaf E, Paglia-Boak A. Drug use among Ontario students 1977-2005. OSDUS highlights. Toronto: Centre for Addiction and Mental Health; 2005. 